\title{
Factors Affecting Customer Retention in Commercial Banks In Tanzania; A Case Of Azania Bank Arusha
}

\author{
Elizabeth Auniel, Dr. Samuel Obino Mokaya \\ Jomo Kenyatta University of Agriculture and Technology, Kenya
}

\begin{abstract}
Customer retention is an important element of any banking strategy in today's increasingly competitive environment. Due to its importance, this study examined factors that affecting customer retention in commercial banks a case of Azania bank, Arusha. The study adopted a case study research design, where data was collected from 132 customers using questionnaires and conducted interviews with employees. The collected data were analyzed using descriptive and inferential statistics mainly frequencies, percentages and mean. One sample t-test, independent t-test, ANOVA, correlation and regression techniques were used to examine the relationships between customer satisfaction, service quality, customer trust, customer commitment, switching barrier factors and customer retention. Correlation results show a positive relationship between service delivery and customer retention, as is the case with customer relationships and customer retention. Therefore, the majority the respondents were ready to continue being a customer at Azania Bank due to the way services are delivered and customer relationships. In addition, regression analysis show that customers treated with respect by bank staff, latest electronic products, and access to banking services anywhere in the country, staff responding promptly to inquiries and valuing customer feedback are significantly influencing customer retention. Therefore, the study concludes that service quality, service delivery, customer relationships and customer satisfaction are positively related to customer retention.
\end{abstract}

Keywords: Commercial banks, customer retention, service delivery, service quality,

\section{Introduction}

Customer retention has gained increased value among both goods and service providing firms. It is now regarded important because it has become the banking industry is highly competitive, with banks and other financial institutions. Most bank product developments are easy to duplicate and when banks provide nearly identical services, they can only distinguish themselves on the basis of price and quality (Munyiri, 2014; Ogongo, 2014; Msoka and Msoka, 2014). Therefore, banking institutions in both developed and developing countries have recognized the contributions of customer retention in banking performance, as such have developed and maintained relationships with their customers and providing quality products (Manrai and Manrai, 2007; Mugambi and Kagiri, 2015).

Organizations have different ways of ensuring customer retention depending on the actual functions of each organization (Mugambi and Kagiri, 2015). They include banks developing credit policies with customer needs and expectations, reviewing their customer attraction and retention policies in order not to lose customers to competitors. Improved and availability of multiple product distribution channels, staff at branches being friendly, the use and accessibility of technologies such as mobile phones, ATMs and the internet further increase retention (Chuani, 2017).

In Tanzania, customer retention has become potentially an effective tool used by commercial banks in gaining an invaluable edge and survival in an increasingly competitive banking environment. Due to competition, banks are being forced to devote more resources to their customer retention strategies (Titko 
and Lace, 2010). In this context, how service quality, customer satisfaction, customer retention, and service delivery affect customer retention in commercial banks, was the basis the study.

\section{Purpose}

The purpose of the study was to assess factors affecting customer retention in the banking industry in Tanzania, using Azania Bank in Arusha as a case for the study. Specifically, the study sought to assess the quality of services provided, service delivery mechanisms and the role of customer relationships in customer retention.

\section{Research Methodology}

This study employed a cross-sectional case study research design to enable collection of data on more than one case and at a single point in time in order to collect a body of quantitative and quantifiable data in connection with two or more variables. The sample covered in the study was 132 respondents drawn from a total population of 2500 .

Data collection was done using survey questionnaire and interviews with key respondents. Before its administration, the questionnaire was pre-tested to ensure collection of valid and reliable data. As part of data collection, the study conducted a documentary review of various documents, including bank policies, retention strategies, procedures on offering customer service, and previous studies. These helped to obtain proper perspectives and adequate grounding of the constructs under study.

Both descriptive and inferential statistical tools were used in the data analysis. Descriptive statistical tools included frequencies, percentages and mean while inferential statistical tools included one sample t-test, independent t-test, ANOVA, correction and regression. Whereas descriptive statistics were used to determine and describe the status of the variables under study, inferential statistics were used to determine and explain their variables relationships. Qualitative data were analyzed by the use of content analysis and reportedly concurrently with quantitative data.

\section{Results and Discussion}

\section{Quality of Service Affecting Customer Retention}

Types of services provided by Azania Bank include deposits facilities, credit facilities, mobile banking, internet banking, western union, telegraphic transfer and TRA and TBL collection accounts. In measuring the quality of services provided by Azania Bank the study carried out one sample T-test to determine the overall mean score and see whether there is a significant quality of services provided or not. The results from one sample statistics the overall mean of quality level score of 3.4826 was higher than the normal quality score 3.0. Thus, one sample T-test results confirm that the level of quality of products is significantly higher than the test value of 3.0 with a $p$ value of 0.000 (Table 4.1 and Table 4.2). As such, in general the products offered by the bank are perceived as of higher quality by customers and thus are satisfied and hence remain at the bank.

Table 1: One-Sample Statistics for quality of products

\begin{tabular}{|l|c|c|c|c|}
\hline & $\mathbf{N}$ & Mean & Std. Deviation & Std. Error Mean \\
\hline Customer satisfaction & 132 & 3.4826 & .42543 & .03703 \\
\hline
\end{tabular}

Table 2: One-Sample Test results for quality of products

\begin{tabular}{|l|c|c|c|c|c|c|}
\hline & \multicolumn{5}{|c|}{ Test Value = 3 } \\
\cline { 2 - 7 } & T & Df & $\begin{array}{c}\text { Sig. (2- } \\
\text { tailed) }\end{array}$ & $\begin{array}{c}\text { Mean } \\
\text { Difference }\end{array}$ & $\begin{array}{c}\text { 95\% Confidence Interval of the } \\
\text { Difference }\end{array}$ \\
\cline { 5 - 7 } & & & & Lower & Upper \\
\hline Customer satisfaction & 13.032 & 131 & .000 & .48258 & .4093 & .5558 \\
\hline
\end{tabular}

Besides the overall mean quality level score of 3.4826 being higher than the normal quality score 3.0, respondents had different perceptions on the quality of products provided by the bank. The study findings 
show that products that have high quality include deposits facilities telegraphic transfer, ATM and, TRA and TBL collection accounts. Also, products that somehow have high quality are credit facilities and western union, while products that have low quality include mobile banking, money gram and internet banking. Therefore, the bank needs to improve all products so that its quality can increase from its current level to very high level, to meet customers' needs.

\section{Quality of Service to Customer Retention}

The study findings show that $85 \%$ (112) of the respondents revealed to continue being customers at Azania Bank due to the quality of services provided, while $15 \%$ (20) of the respondents revealed to continue due to services provided. This findings show need for Azania bank to improve services that their performances are still low to retain more customers. Also, it was revealed that all customers use two products such as deposits and ATM, the quality of these products are perceived to have high quality, thus the majority of customers are satisfied with products and thus cannot move to another bank.

Various scholars have supported study findings differently; Daniel (2016) in his study in commercial in Kenya found adoption of service quality practices such as effective communication, customer trust, customer satisfaction, price changes, the level of involvement in commercial banks has significant impact on customer retention. Also, Zangmo et al., (2015) supports that service quality plays an important role in retaining customers, and thus service quality has a positive and significant relationship with customer retention. Likewise, study by Parasuraman et al. (2002) and Kassim (2006) supports that there is a positive impact of service quality on customer loyalty and retention.

\section{Effect of Service Delivery to Customer Retention}

The study revealed the different ways used by the bank in service delivery, these include; very prompt in handling customer issues, short time for customers to get services after enquiry and highly access to electronic transactions. Others are professionalism in service delivery, convenient location of the bank and promptly informed of new products and services.

The study to determine effect of service delivery to customer retention in Azania Bank Arusha, correlation analysis was computed to assess the relationship between service delivery in the bank and customer retention. Table 4.3 show a positive correlation between the service delivery to customer retention, $(r=-$ $0.382, \mathrm{n}=132, \mathrm{p}<0.00$ ). As such, there was a strong, positive correlation between service delivery and customer retention. Improvement of service delivery is correlated with customer retention (Table 3).

Table 3: Correlations between service delivery and customer retention

\begin{tabular}{|l|l|c|c|}
\hline \multicolumn{2}{|c|}{} & $\begin{array}{c}\text { Customer } \\
\text { retention }\end{array}$ & \begin{tabular}{c} 
Service delivery \\
\hline \multirow{2}{*}{$\begin{array}{l}\text { Customer } \\
\text { retention }\end{array}$}
\end{tabular} \\
\cline { 2 - 4 } & Pearson Correlation & 1 & $-.382^{* *}$ \\
\cline { 2 - 4 } & Sig. (2-tailed) & 132 & .000 \\
\hline \multirow{3}{*}{ Service delivery } & $\mathrm{N}$ & 132 \\
\cline { 2 - 4 } & Pearson Correlation & $-.382^{* *}$ & 1 \\
\cline { 2 - 4 } & Sig. (2-tailed) & .000 & 132 \\
\cline { 2 - 4 } & $\mathrm{N}$ & 132 & \\
\hline \multirow{2}{*}{$* *$ Correlation } & is significant at the 0.01 level (2-tailed). \\
\hline
\end{tabular}

In addition, the relationship between service delivery and customer retention has been discussed widely by various scholars. Ogunnaike et al. (2014) in their study tested the relationship between effective customer service delivery and customer retention using correlation coefficient and found a strong positive correlation between customer service delivery and customer retention. Also, Haruna (2015) in his study on quality service delivery and customer retention in the banking industry in Ghana found also a significant relationship between service delivery and customer retention.

\section{Role of Customer Relationships in Customer Retention}


The study found the bank building and strengthening the relationship through personal recognition, provide customer support, providing special offers on its products, rewarding customers and great concern on issues affecting customers. The study conducted further analysis to test if customer relationships and customer retention correlate statistically. The results show a positive correlation between customer relationships and customer retention, $(\mathrm{r}=-0.476, \mathrm{n}=132, \mathrm{p}<0.00)$ as shown in Table 4. As such, there was a strong and positive correlation between customer relationships and customer retention. Therefore, it is implicit that improvement of relationships with customers resulted to customer retention.

Table 4: Correlations between customer relationships and customer retention

\begin{tabular}{|l|l|c|c|}
\hline \multicolumn{2}{|l|}{} & $\begin{array}{c}\text { Customer } \\
\text { retention }\end{array}$ & Service delivery \\
\hline \multirow{3}{*}{ Customer retention } & Pearson Correlation & 1 & $-.476^{* *}$ \\
& Sig. (2-tailed) & & .000 \\
& $\mathrm{~N}$ & 132 & 132 \\
\hline \multirow{3}{*}{ Service delivery } & Pearson Correlation & $-.476^{* * *}$ & 1 \\
& Sig. (2-tailed) & .000 & 132 \\
\hline
\end{tabular}

**. Correlation is significant at the 0.01 level (2-tailed).

The study findings are in line with that of Madziwa (2016) who points out that there is a strong influence of the relationship between customers and bank with its customers and customer retention. It is argued that listening to customers' needs improves relationship with customers. Further, Tauni et al. (2014) support that customer relationships contribute more than $68 \%$ on retaining the customers. The customer relationship is built effectively through providing value added services which match with customer needs.

\section{The Linkage between Customer Satisfaction and Customer Retention}

To measure the effect of customer satisfaction to customer retention, regression analysis was done (Table 5). The results (R Square .212) show the independent variables under study account for $21 \%$ of variations in the dependent variable (customer retention). The results also indicate that the estimation of customer retention using the model can only be wrong by $69 \%$ (Std. Error 0.69453). The implication is that there are other additional factors that influence customer retention, hence the need for more detailed studies on the subject.

Table 5: Model summary

\begin{tabular}{|c|c|c|c|c|}
\hline Model & $\mathrm{R}$ & R Square & Adjusted R Square & Std. Error of the Estimate \\
\hline 1 & $.460 \mathrm{a}$ & .212 & .168 & 0.69453 \\
\hline
\end{tabular}

a. Predictors: (Constant), Customer satisfaction

ANOVA test was also conducted to determine whether the model works in explaining the relationship among variables as postulated in the conceptual model. The results in Table 6 show an F value of 4.767 with a significance level of 0.000 which is far lower than the confidence level of 0.05 , hence establishing a significant relationship. The implication is that each independent variable contributes significantly to changes in the dependent variable. This shows that the model works and thus accounts for significantly more variance in the dependent variable than would be expected by chance.

Table 6: ANOVA ${ }^{\mathrm{a}}$

\begin{tabular}{|l|l|c|c|c|c|c|}
\hline \multicolumn{2}{|l|}{ Model } & Sum of Squares & Df & Mean Square & F & Sig. \\
\hline \multirow{4}{*}{1} & Regression & 16.095 & 7 & 2.299 & 4.767 & $.000^{\mathrm{b}}$ \\
\cline { 2 - 7 } & Residual & 59.814 & 124 & .482 & & \\
\cline { 2 - 7 } & Total & 75.909 & 131 & & & \\
\hline
\end{tabular}

a. Dependent Variable: Customer retention

b. Predictors: (Constant), Customer satisfaction

The model shows that customers treated with respect by bank staff, latest electronic products, access to banking services anywhere in the country, staff responding promptly on enquiries and valuing customer 
feedback are significant since all their P-values are less than 0.05 (Table 7). Linear regression results imply that a customer valued by the bank and staff delivering services and being treated with respect does not significantly influence customer retention. The findings are consistent with those of a study by Odunlami (2015) which supports that that customer satisfaction independently accounts for $71.7 \%$ of the variation in customer retention. Effective satisfaction of customers gives room for customer retention.

\section{Table 7: Coefficients}

\begin{tabular}{|c|c|c|c|c|c|c|}
\hline \multirow{2}{*}{\multicolumn{2}{|c|}{ Model }} & \multicolumn{2}{|c|}{$\begin{array}{c}\text { Unstandardized } \\
\text { Coefficients }\end{array}$} & \multirow{2}{*}{$\begin{array}{c}\text { Standardized } \\
\text { Coefficients } \\
\text { Beta } \\
\end{array}$} & \multirow[b]{2}{*}{$\mathrm{t}$} & \multirow[b]{2}{*}{ Sig. } \\
\hline & & $\mathrm{B}$ & Std. Error & & & \\
\hline \multirow[t]{8}{*}{1} & (Constant) & 1.632 & .332 & & 4.918 & .000 \\
\hline & Valued by the bank & .136 & .127 & .161 & 1.067 & .288 \\
\hline & $\begin{array}{l}\text { Treated with respect } \\
\text { by bank staff }\end{array}$ & -.301 & .139 & -.320 & -2.165 & .032 \\
\hline & $\begin{array}{l}\text { Latest electronic } \\
\text { products }\end{array}$ & .256 & .082 & .343 & 3.125 & .002 \\
\hline & $\begin{array}{l}\text { The staff who deliver } \\
\text { the service }\end{array}$ & .098 & .106 & .119 & .925 & .357 \\
\hline & $\begin{array}{l}\text { Access to banking } \\
\text { services anywhere in } \\
\text { the country }\end{array}$ & -.318 & .068 & -.459 & -4.703 & .000 \\
\hline & $\begin{array}{l}\text { Staff responding } \\
\text { promptly on enquiries }\end{array}$ & -.328 & .106 & -.382 & -3.086 & .003 \\
\hline & $\begin{array}{l}\text { Valuing customer } \\
\text { feedback }\end{array}$ & .444 & .107 & .565 & 4.142 & .000 \\
\hline
\end{tabular}

\section{Conclusions}

Qualities of services provided to customers vary from one service to another. Services that have low quality based on customers' satisfaction perception include mobile banking, internet banking and money gram, which need to be improved to meet customers' need. Besides, different levels of quality of services from one service to another, a still customer intends to continue being served by the bank. This shows that services having high quality such as deposits, ATM and credit, are enjoyed by all customers and have influence to customers retention at the bank.

Further, the way service is delivered to customers is an important element in retention. The bank has been able to retain customers due to different ways used in delivering services to customers. The significant difference in service delivery among customers retained by the bank for 8 years and above, and those serviced by the bank for 2-4 years, have not resulted in decision of customers switching to other banks due to the overall satisfaction of service delivery.

The bank provides quality services to strengthen customer relationship, with personal recognition, customer support, giving special offers and rewarding customers to improve retention. This has created cyclical reciprocation whereby, customers are motivated to remain with the bank. It is also clear that the Bank's effort in building customers relationship has grounding to marketing theory which proposes that a successful relationship requires time and efforts to develop. Customers are retained at the bank due to high satisfaction levels. Customers treated with respect by bank staff, latest electronic products, and access to banking services anywhere in the country, staff responding promptly on enquiries and valuing customer feedback have contributed to customer satisfaction and retention.

\section{Recommendations}

Based on the study findings, the Bank should improve on its products to customers including mobile money, MoneyGram and internet banking. These services were found to be of low quality, thus its improvements are important for easy accessibility. The number of women bank customers is lower compared to men. The bank 
needs to provide more education to women trough community based-organizations owned by women on the importance of having bank accounts. Further, the bank should ensure that all customers are equally valued by staff to increase satisfaction levels. Customers were of the opinion that the interest rates charged on loans is high, thus the bank should make sure the interest rate is lowered or negotiated with customers for some of types of credit. The difference existing in satisfaction level with service delivery between customers served by the bank for 8 years and above, and customers served by 2-4 years, should be improved so that all customers can have equal satisfaction levels. In addition, the bank should allow customers to negotiate with the bank staff when they perceive the interest rate charged is higher, so that interest on loan charged can be friendly to them. Further, the bank should provide a mechanism through which customers can report when they face challenges in accessing services, so that appropriate actions can be taken to solve such issues.

\section{References}

[1] Abdul-Fatawu, H. (2016). Quality service delivery and customer retention in the banking industry in Ghana, the mediating role of Customer Relationship Management (CRM). Dissertation submitted for Award of Masters' Degree at Kwame Nkrumah University of Science and Technology (KNUST), Ghana.

[2] Chuani, P. W. (2017). Determinants of Customer Retention in Kenyan Commercial Banks: A Case of KCB Bank Kenya Limited. Dissertation submitted for Doctoral Degree at United States International University-Africa, Kenya.

[3] Daniel, W.S. (2016). Effects of Service Quality on Customer Retention among Commercial Banks in Kenya. A Research Project Report Submitted for Award of Masters' Degree at University of Nairobi, Kenya.

[4] Haruna, A. (2015). Quality Service Delivery and Customer Retention In The Banking Industry In Ghana, The Mediating Role of Customer Relationship Management (CRM). A Thesis Submitted for Award of Master' Degree at Kwame Nkrumah University of Science and Technology (KNUST), Ghana.

[5] Madziwa, S. (2016). Influence of Customer Relationship Management on Customer Retention in Sacco Industry. A Project Report Submitted for Award of Masters' Degree at United States International University-Africa, Kenya.

[6] Manrai, L. A., \& Manrai, A. K. (2007). A field study of customers' switching behavior for bank services. Journal of Retailing and Consumer Services, 14(3), 208-215.

[7] Msoka, C. M., \& Msoka, E. M. (2014). Determinants of Customer Retention in Commercial Banks in Tanzania. Journal of Finance and Bank Management, 2(1), 9-30.

[8] Mugambi, M.N and Kagiri, A.W. (2015). Effects of Customer Retention Strategy on Performance of Commercial Banks in Kenya. International Journal of Science and Research (IJSR), 4(6), 44-49.

[9] Munyiri, L. N. (2014). Competitive strategies and customer retention among commercial banks in Kenya. A Research Project submitted for Award of Masters' Degree at University of Nairobi, Kenya.

[10] Odunlami, I.B. (2015). Impact of Customer Satisfaction on Customer Retention: A Case Study of a Reputable Bank in Oyo, Oyo State. Nigeria. International Journal of Managerial Studies and Research (IJMSR) 3 (2), 42-53.

[11] Ogongo, E. (2014) Customer Retention Strategies Adopted By Commercial Banks in Kenya. A Research Project submitted for Award of Masters' Degree at University of Nairobi, Kenya.

[12] Ogunnaike, O.O., Sholarin, A., Salau, O., \& Borishade, T. T (2014). Evaluation of Customer Service and Retention: A Comparative Analysis of Telecommunication Service Providers. European Journal of Business and Social Sciences, 3(8), 273-288.

[13] Parasuraman, A. (1997). Reflections on Gaining Competitive Advantage through Customer Value. Journal of the Academy of Marketing Science, 25(2), pp. 154-161.

[14] Tauni, S., Khan, I.R.,Durrani, M.K., \&Aslam, S. (2014). Impact of Customer Relationship Management on Customer Retention in the Telecom Industry of Pakistan. Industrial Engineering, 4(10), 54-59.

[15] Titko, J., \& Lace, N. (2010). Customer satisfaction and loyalty in Latvian retail banking. Economics \& Management, 15(1).

[16] Zangmo, M. Liampreecha, W. Chemsripong, S. (2015). The impact of service quality on customer retention in airline industry of Bhutan. International Business Management 9 (6) 1281-1284. 
